\title{
Exploring How IT teachers implementing Active Learning Strategies at Al-Baha University
}

\author{
Alghamdi, Fayiq \\ Al-Baha University \\ Education College \\ Al- Baha, Saudi Arabia \\ Fsaeed@bu.edu.sa
}

\begin{abstract}
We know that Active Learning Strategies, ALS is implemented in High Education. What is not well understood is the range of using the ALS among IT teachers at Al-Baha University. This project explores how teachers are managing ALS and understand CS teachers' viewpoints on how active learning is implementing. We adopt the active learning techniques made by the Center for Research on Learning and Teaching, the University of Michigan as the base. Data was collected through a sample survey with $10 \mathrm{CS}$ teachers in the IT department at Al-Baha University. The researcher used frequencies, arithmetic means, standard deviations, and percentages. This project determines the CS teachers' experiences in using ALS in their courses. The findings of this project are only 7 strategies out of 13 are applied. Results showed that the CS teachers used Clarification and Group in the most. The results could help to improve the CS teachers to grasp the sophisticated strategies and implement them in their teaching.
\end{abstract}

\section{Keywords-IT Teachers, Active Learning, teaching, CS}

\section{INTRODUCTION}

Research shows that active learning strategies, ALS have a strong positive relationship with student learning outcomes in STEM [1]. Active learning, which is studentcentric is adopted in Institutions of Higher Education nowadays. Students are likely to be exposed to a more indepth understanding from courses and general skills practices in ALS where teachers are in a position to raise students' motivation on how to learn.

Pears et al. highlighted the most common individual practices in the IT department which are group work and peer learning [2]. Marks said learners do not know what is appropriate for them in their learning and teachers should work as facilitator [20].

These research goals are to explore challenges facing IT teachers at Al-Baha University, ABU in adopting the ALS, to compare different active learning strategies in order to identify the most used, and to sample the views of CS teachers on how active learning is being implemented.

Alghamdi and Deraney [11] highlight how the active learning method can be a successful effort when use at university as the main method. In this study. The sample covered 256 female students. The value of active learning was marked by quantitative analyses of the final exam. Results of the study showed that active learning significantly increased the overall skills of the students.

The study of Al Kaabneh and Hussein (12) aimed at identifying the extent to which students of Physical Education colleges have implemented active learning skills of Teaching in Jordanian universities. The researcher used the descriptive approach to suit the nature of this study. The study sample consisted of (88) A faculty member distributed among the colleges of physical education in Jordanian universities, and the researcher used the program Statistical (SPSS). He reached conclusions and recommendations, which are that the extent to which students of physical education colleges have implemented active learning skills did not live up to the desired level and that the level of students' implementation of active learning skills was moderate

Wilke's study [13] conducted a study aimed at investigating the effect of employing active learning strategies on motivation and self-efficacy for students of Angelo University in Texas in the US in the Physiology course. The study is on an experimental group that the course was taught by employing active learning strategies and a control group that was taught in the lecture style. The individuals of the two samples underwent a standardized achievement test in the same course, and the results of the achievement test showed that the results of the experimental group students were much better than the results of the control group students. It also showed that the students in the experimental and control groups had positive trends towards active learning.

Ayasreh's study [14] find out the degree of following active learning strategies throughout field training, from the view of female students at Hail University. It also aims to understand the degree of teachings and theoretical knowledge, and proposed to identify the obstacles to applying active learning strategies. The descriptive approach was used. The study sample consisted of (53) students. The study used a questionnaire as a tool with (33) paragraphs. The results showed that the knowledge of the principles and theoretical foundations of the active learning strategies with an intermediate score.

This research focuses on combined with the importance of student transaction from teacher-centric to student-centric. However, it is the first exploring IT teachers at $\mathrm{ABU}$ about implementing an active learning strategy.

\section{ACTIVE LEARNING STRATEGIES (ALS)}

\section{A. Active Learning}

The higher institution education research literature has been shaped recently as a result of significant research work and attitude towards active learning in higher education. It happened when the educational focuses shifted from the teacher-centric to the student-centric in the 1980s. [8,9]. In order to implement the ALS, teachers require an organization and physical structure that allow learners to access resources 
and develop different professional skills such as self-directed learning, problem-solving, critical thinking, finding educational resources, communication, and teamwork. The ALS requires teachers to get robust training for effective implementation of the strategies. In the strategies, there are times for preparation, times for updating lectures, and times to engage students. Teachers must play an essential role in facilitating the students' group engagement. Active learning defined differently concerning context and discipline of study.

Active learning is a relationship between teachers and students where students take the most part in their learning processes.

\section{B. The University of Michigan Center}

The active learning techniques designed by the Center for Research on Learning and Teaching, the University of Michigan [4.5.6.7] are being adopted in this study. This is illustrated in As you can see in Figure [1].

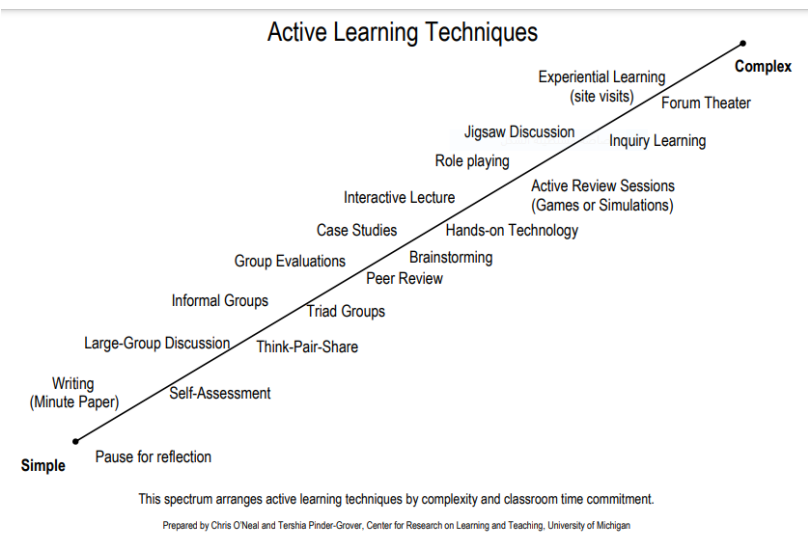

Figure [1] The different ALS distributed based on complexity and classroom time commitment.

As you can see, this study chooses only 13 strategies that is popular at higher education in Saudi Arabia. It was negotiation with professors at $\mathrm{ABU}$. Active learning occurs when "students explicitly participate in their attainment of knowledge. Students often have difficulty connecting concepts and principles learned in class to specific cases or other frames of references" [15]. In other words, we can say students actively learn who is "doing" and explicitly "thinking" as they are learning [16].

Lumpkin and colleagues [17] correspond that, active learning includes often in contrast to traditional lecturing, "any activity encouraging students to participate in learning approaches engaging them with course material and enhancing critical thinking as they make applications".

The author encouraged instructors to include more active learning strategies and assessments in their teaching. According to Meyers and Jones, the core of ALS is the commitment of the minds of students in recalling and involving their previous knowledge and in making associations between new knowledge and former knowledge [18].
In concurrence with the literature, Unruh and Obeidat's highlighted the active learning approach in Saudi higher education in general, the scholars advise teachers to explicitly teach comprehension skills and metacognitive. Saudi students at higher education are also accustomed to practicing a more passive role in their learning and may need support [19].

Around the world, many universities established a center that help teachers and students to be active. For example of active learning center:

1- Oregon TECH

https://www.oit.edu/faculty-

staff/committees/commission-college-

teaching/active-learning-center.

2- Georgia College https://www.gcsu.edu/ctl/activelearning-center-for-teaching-and-learning.

3- University of Minnesota https://cei.umn.edu/activelearning.

4- Purdue University https://www.purdue.edu/activelearning/.

5- Uppsala University https://www.uu.se/asp/?languageId=1

At ABU, the Department of Faculty's skills development is tacking this path. The active learning strategies is one of their programs.

\section{DEPARTMENT OF FACULTY's SKILLS DEVELOPMENT AT $\mathrm{ABU}$}

It was established at the end of 2017. The target is evaluation, measurement, and strategic planning for staff at ABU. It takes responsibility for planning workshops, training programs and develops academic skills and all that would develop the university's outputs. The vision is guidance in the development of faculty members of the skills in line with the Saudi Vision 2030.

This department offers many programs related to teaching and academic skills, the Active learning strategies was one of them. This is the first investigation of the value of the Department of Faculty's Skills Development at ABU in Active Learning Strategies. The 55\% of the sample have participated once at least in the last year. This center should help teachers and students to learn the active strategies [21].

\section{IV.METHODOLOGY}

In this project, the researcher wants to understand what active learning strategies (ALS) teachers in IT department use, how they are implemented, and the influence of the pedagogy program. The research selected 13 strategies out of 19 that is from the Center for Research on Learning and Teaching, the University of Michigan that is most common in ABU and it was discussed with professors. The researcher developed survey based on active learning and the satisfaction of the Department of Faculty's Skills Development at ABU.

The main question is: How do CS teachers implement active learning strategies in their courses? 
This question is divided to:

1- Which active learning strategies are preferred by IT teachers?

2- How do IT teachers support students to be active learners?

3- What is the satisfaction of IT teachers for programs offered by the Department of Faculty's Skills Development at ABU?

The survey contends two parts. The first is general information. The second part is questions related to Active Learning Strategies and what/how the most techniques teachers choose in their teaching.

The staff at $\mathrm{ABU}$ are 453 female and 829 male teachers and researchers. The IT department has 58 teachers. We contacted the dean of the IT department by e-mail and asked them to distribute the survey among their list. We received 10 responses which is $18 \%$ of the community.

\section{RESULTS}

This project has limited time and the response was from ten IT teachers. They also had a different period of experience in CS teaching.

TABLE I. THE PARTICIPANTS AND THE TEACHING EXPERIENCES

\begin{tabular}{|l|cc|c|c|}
\hline \multirow{2}{*}{ Participants } & \multicolumn{3}{|c|}{ Experience } \\
\cline { 2 - 4 } & \multicolumn{1}{|c|}{$\mathbf{1 - 5}$} & $\mathbf{6 - 1 0}$ & $\mathbf{+ 1 1}$ \\
\hline 10 & 2 & 4 & 4 \\
\hline
\end{tabular}

In the survey, the list of 13 active learning strategies by the Center for Research on Learning and Teaching, the University of Michigan was described and the IT teachers choose one of them based on their experiences, only 7 strategies picked up.

TABLE II.

THE ANSWERING OF THE FIRST QUESTION

\begin{tabular}{|l|l|l|l|l|}
\hline Are you using .. & Always & Sometime & Rarely & never \\
\hline Clarification Pauses & 5 & 4 & 1 & 0 \\
\hline Writing Activities & 0 & 5 & 4 & 1 \\
\hline Self-Assessment & 3 & 2 & 4 & 1 \\
\hline Group Discussion & 4 & 4 & 2 & 0 \\
\hline Think-Pair-Share & 2 & 5 & 2 & 1 \\
\hline Peer Review & 1 & 4 & 3 & 2 \\
\hline Brainstorming & 3 & 5 & 2 & 0 \\
\hline Case Studies & 3 & 5 & 1 & 1 \\
\hline Hands-on Technology & 2 & 3 & 3 & 2 \\
\hline
\end{tabular}

\begin{tabular}{|l|l|l|l|l|}
\hline Interactive Lecture & 3 & 5 & 1 & 1 \\
\hline Jigsaw Discussion & 1 & 3 & 3 & 3 \\
\hline Student as teacher & 1 & 6 & 3 & 0 \\
\hline Experiential Learning & 1 & 5 & 2 & 2 \\
\hline
\end{tabular}

How do CS teachers implement active learning strategies in their courses?

This question is divided to:

1- Which active learning strategies are preferred by IT teachers?

To answer this question, the researcher used frequencies, arithmetic means, standard deviations, and percentages, and this is evident in the following table III

TABLE III. ACTIVE STRATEGIES WERE PREFERRED

\begin{tabular}{|c|c|c|c|c|c|c|}
\hline Statments & Mean & $\begin{array}{c}\text { Std. } \\
\text { Deviation }\end{array}$ & Ratio & $\mathbf{t}$ & trend & Rank \\
\hline $\begin{array}{l}\text { Clarification } \\
\text { Pauses }\end{array}$ & 3.400 & 0.699 & 85 & 6.33 & Always & 1 \\
\hline Writing Activities & 2.400 & 0.699 & 60 & 1.81 & Rarely & 8 \\
\hline Self-Assessment & 2.700 & 1.059 & 67.5 & 2.09 & sometime & 6 \\
\hline Group Discussion & 3.200 & 0.789 & 80 & 4.81 & sometime & 2 \\
\hline Think-Pair-Share & 2.800 & 0.919 & 70 & 2.75 & sometime & 5 \\
\hline Peer Review & 2.400 & 0.966 & 60 & 1.31 & Rarely & 8 \\
\hline Brainstorming & 3.100 & 0.738 & 77.5 & 4.71 & sometime & 3 \\
\hline Case Studies & 3.000 & 0.943 & 75 & 3.35 & sometime & 4 \\
\hline $\begin{array}{l}\text { Hands-on } \\
\text { Technology }\end{array}$ & 2.500 & 1.080 & 62.5 & 1.46 & sometime & 7 \\
\hline $\begin{array}{l}\text { Interactive } \\
\text { Lecture }\end{array}$ & 3.000 & 0.943 & 75 & 3.35 & sometime & 4 \\
\hline Jigsaw Discussion & 2.200 & 1.033 & 55 & 0.61 & Rarely & 9 \\
\hline Student as teacher & 2.800 & 0.632 & 70 & 4.00 & sometime & 5 \\
\hline $\begin{array}{l}\text { Experiential } \\
\text { Learning }\end{array}$ & 2.500 & 0.972 & 62.5 & 1.63 & sometime & 7 \\
\hline
\end{tabular}

It is clear from the previous table that:

- The preference of the sample members for each of the active learning strategy and the Clarification strategy came first, with an average of (3.40), and a percentage (85\%). Therefore, the trend of the sample members to use these strategies came (Always).

- The preference of the sample members for using the Group Discussion strategy came in second place with an average of (3.20) and a percentage (80\%). Therefore, the trend of the sample members to use this strategy came (sometime). 
- The preference of the sample members for using the brainstorming strategy came in third place, with an average of (3.10) and a percentage (77.5\%). Therefore, the trend of the sample members to use this strategy came (sometime).

- The preference of the sample members for each of the Case Studies strategy and Interactive Lecture strategy came in fourth place with an average of (3.0), and a percentage $(75 \%)$. Therefore, the trend of the sample members to use these strategies came (sometime).

- The preference of the sample members for both using the Think-Pair-Share strategy and the Student as Teacher strategy came in fourth place with an average of (2.80), and a percentage $(70 \%)$. Therefore, the trend of the sample members to use these strategies came (sometime).

2- How do IT teachers support students to be active learners?

To answer this question, the researcher used frequencies, arithmetic means, standard deviations, and percentages, and this is evident in the following table IV

TABLE IV. IT TEACHERS SUPPORT STUDENTS

\begin{tabular}{|l|l|l|l|l|l|l|}
\hline \multicolumn{1}{|c|}{ Statments } & Mean & $\begin{array}{c}\text { Std. } \\
\text { Deviation }\end{array}$ & Ratio & t & trend & Rank \\
\hline $\begin{array}{l}\text { Teachers give the } \\
\text { students enough } \\
\text { support to be } \\
\text { active in their } \\
\text { learning }\end{array}$ & 3.400 & 0.966 & 85 & 4.58 & Always & 1 \\
\hline $\begin{array}{l}\text { The time is the } \\
\text { issue that do not } \\
\text { allowed teachers } \\
\text { implement the } \\
\text { ALS } 2.700\end{array}$ & 0.483 & 67.5 & 4.58 & sometime & 3 \\
\hline $\begin{array}{l}\text { The workload is } \\
\text { the issue that do } \\
\text { not allowed } \\
\text { teachers } \\
\text { implement the } \\
\text { ALS }\end{array}$ & 3.000 & 0.816 & 75 & 3.87 & sometime & 2 \\
\hline $\begin{array}{l}\text { The environment } \\
\text { is the issue that do } \\
\text { not allowed } \\
\text { teachers } \\
\text { implement the } \\
\text { ALS }\end{array}$ & 2.600 & 1.174 & 65 & 1.62 & sometime & 4 \\
\hline $\begin{array}{l}\text { The lack or } \\
\text { teachers training in } \\
\text { active learning is } \\
\text { the issue that do } \\
\text { not allowed } \\
\text { teachers } \\
\text { implement the } \\
\text { ALS }\end{array}$ & & 1.075 & 60 & 1.18 & Rarely & 5 \\
\hline
\end{tabular}

It is clear from the previous table that:

- The sample members 'use of (Teachers give the students enough support to be active in their learning) came first, with an average of (3.40), and a percentage ( $85 \%)$, and thus came the direction of their use of it (Always)
- The use of the sample members of (The workload is the issue that do not allowed teachers to implement the ALS) came in second place with an average of (3.00) and a percentage $(75 \%)$ and thus came the direction of their use of it (sometime)

The sample's use of (The time is the issue that do not allowed teachers to implement the ALS) came in third place with an average of (2.70) and a percentage (67.5\%) and thus came the direction of its use (sometime)

The sample's use of (The environment is the issue that do not allowed teachers to implement the ALS) came in fourth place with an average of (2.60) and a percentage (65\%) and thus came the direction of its use (sometime)

- The sample's use of (The workload is the issue that do not allowed teachers to implement the ALS) came in fifth place with an average of (2.40) and a percentage (60\%).

3- What is the satisfaction of IT teachers with programs offered by the Department of Faculty's Skills Development at ABU?

To answer this question, the researcher used frequencies, arithmetic means, standard deviations, and percentages, and this is evident in the following table $\mathrm{V}$

TABLE V. THE SATISFACTION OF IT TEACHERS

\begin{tabular}{|c|c|c|c|c|c|c|}
\hline Statments & Mean & $\begin{array}{c}\text { Std. } \\
\text { Deviation }\end{array}$ & Ratio & $\mathbf{t}$ & trend & Rank \\
\hline $\begin{array}{l}\text { Are you satisfied } \\
\text { with the training } \\
\text { program in } \\
\text { pedagogy that is } \\
\text { offered by the } \\
\text { Department of } \\
\text { Faculty's Skills } \\
\text { Development at } \\
\text { ABU? }\end{array}$ & 2.700 & 0.483 & 67.5 & 4.58 & sometime & 2 \\
\hline $\begin{array}{l}\text { The workload is } \\
\text { the issue that do } \\
\text { not allowed } \\
\text { teachers } \\
\text { implement the } \\
\text { ALS }\end{array}$ & 3.000 & 0.816 & 75 & 3.87 & sometime & 1 \\
\hline $\begin{array}{l}\text { The environment } \\
\text { is the issue that do } \\
\text { not allowed } \\
\text { teachers } \\
\text { implement the } \\
\text { ALS }\end{array}$ & 2.600 & 1.174 & 65 & 1.62 & sometime & 3 \\
\hline $\begin{array}{l}\text { The lack or } \\
\text { teachers training } \\
\text { in active learning } \\
\text { is the issue that do } \\
\text { not allowed } \\
\text { teachers } \\
\text { implement the } \\
\text { ALS }\end{array}$ & 2.400 & 1.075 & 60 & 1.18 & Rarely & 4 \\
\hline $\begin{array}{l}\text { Are you satisfied } \\
\text { with the training } \\
\text { program } \\
\text { research that is } \\
\text { offered by the } \\
\text { Department of } \\
\text { Faculty's Skills }\end{array}$ & 1.700 & 1.494 & 42.5 & 0.63 & never & 6 \\
\hline
\end{tabular}




\begin{tabular}{|l|l|l|l|l|l|l|}
\hline $\begin{array}{l}\text { Development at } \\
\text { ABU }\end{array}$ & & & & & & \\
\hline $\begin{array}{l}\text { Are you satisfied } \\
\text { with the training } \\
\text { program in higher } \\
\text { education standard } \\
\text { that is offered by } \\
\text { the Department of } \\
\text { Faculty's Skills } \\
\text { Development at } \\
\text { ABU }\end{array}$ & 1.476 & 55 & 0.43 & Rarely & 5 \\
\hline Total & $\mathbf{2 . 5}$ & $\mathbf{. 9 4 2}$ & \multicolumn{5}{|c|}{ sometime } \\
\hline
\end{tabular}

It is clear from the previous table that:

- (The workload is the issue that do not allowed teachers to implement the ALS) came first with an average of (3.00) and a percentage $(75 \%)$ and thus the level of satisfaction (sometime)

- (Are you satisfied with the training program in pedagogy that is offered by the Department of Faculty's Skills Development at ABU) came in second place with an average of (2.7) and a percentage $(67.5 \%)$, thus the level of satisfaction came (sometime)

(The environment is the issue that do not allowed teachers to implement the ALS) came in third with an average of (2.60), a percentage $(65 \%)$ and thus the level of satisfaction (sometime).

- The use of the sample members of (the lack or teachers training in active learning is the issue that do not allowed teachers to implement the ALS) came in fourth place with an average of (2.40), and a percentage (60\%), thus the level of satisfaction (Rarely).

- The sample members 'use of (Are you satisfied with the training program in higher education standard that is offered by the Department of Faculty's Skills Development at ABU) came in fifth place with an average of (2.20), and a percentage $(50 \%)$, thus the level of satisfaction came (Rarely)

- The sample members 'use of (Are you satisfied with the training program in higher education standard that is offered by the Department of Faculty's Skills Development at ABU) came in fifth place with an average of (1.70) and a percentage $(42.5 \%)$, thus the level of satisfaction came (never)

- The level of satisfaction came in general at the intermediate level, with an average of (2.5)

\section{VI.DISCCUSTION}

Only seven active learning strategies out of threaten are used by IT teachers at ABU, that is Clarification Pauses, Group Discussion, Brainstorming, Case Studies, Interactive Lecture, Think-Pair-Share and Student as teacher. Some of them agreed with Pears et al. [2], and Alsmainey [22]. The IT teachers need more training program in pedagogy especially for other strategies in Active Learning. Theses seven strategies is appropriate to used in CS education. Teachers are familiar with these strategies; However, university should offer workshops, guidelines and training programs to inherence teachers used active learning in teaching.

Teachers working as facilitator to support student to be active learner; However, the workload and limited time are the issue for IT teachers do not give student enough opportunity to engage in active learning. Minimize the contents or number of students could solve the problem. This point agreed by many research in active learning strategies such as $[3,6]$.

The Department of Faculty's Skills Development at ABU offers many workshops regarding active strategy, but it need more focused in different active strategies that does not picked up by IT teacher for example, Writing Activities, Jigsaw Discussion and Experiential Learning.

\section{CONCOLSION}

This work explores how IT teachers are applying ALS. The active learning techniques made by the Center for Research on Learning and Teaching, the University of Michigan, were used after the modifying with the Saudi higher education environment. Data was collected through a survey with 10 IT teachers. The researcher used frequencies, arithmetic means, standard deviations, and percentages. The outputs of this project are IT teachers only used seven strategies out of 13 are applied. The Department of Faculty's skills development needs to improve programs that IT teachers learn other strategies and help teachers and students to implement them in their duties. The coming research will go deeper with students about how they act as an active learner.

\section{REFERENCES}

1. S. Freeman, S. L. Eddy, M. McDonough, M. K. Smith, N. Okoroafor,H. Jordt, and M. P. Wenderoth, "Active learning increases student performance in science, engineering, and mathematics," Proceedings of the National Academy of Sciences, vol. 111, no. 23, pp. 8410-8415,2014. [Online]. Available: http://www.pnas.org/content/111/23/8410.abstract

2. A. Pears, A. Nylén and M. Daniels, "A critical analysis of trends in student-centric engineering education and their implications for learning," 2016 IEEE Frontiers in Education Conference (FIE), 2016, pp. 1-7, doi: 10.1109/FIE.2016.7757715. Active learning. (n.d.). Retrieved September 1, 2005, from University of California at Davis, Teaching Resources Center Web http://trc.ucdavis.edu/trc/ta/tatips/activelearning.pdf.

3. C. Bonwell, "Enhancing the lecture: Revitalizing a traditional format. In T.E. Sutherland, C.C. \& Bonwell (Eds.), Using active learning in college classes: A range of options for faulty. 1996.

4. R, Felder \& $\mathrm{R}$, Brent. "Cooperative learning in technical courses: Procedures, pitfalls, and payoffs".1994.

5. W, McKeachie. "How to make lectures more effective. In Teaching tips: Strategies, research, and theory for college and university teachers (11th ed.) (pp. 52-68). New York: Houghton Mifflin Co. 2005.

6. D, Paulson. \& J, Faust. "Active learning for the college classroom". Retrieved September 1, 2005 , from California State University, L.A. Web site: http://www.calstatela.edu/dept/chem/chem2/Active/ 
7. G. Gibbs, "Learning by doing: A guide to learning and teaching methods," Birmingham: Sced, 1988.

8. A. Morgan, E. Taylor, and G. Gibbs, "Variations in students approaches to studying," British

9. Disciplinary Domain of Science and Technology, "TUR", retched on 12-2-

2019 http://www.teknat.uu.se/aboutus/Educational+development/tur/.

10. A, Alghamdi. \& P, Deraney. " Teaching Research Skills to Undergraduate Students Using an Active Learning Approach: A Proposed Model for Preparatory-Year Students in Saudi Arabia". International Journal of Teaching and Learning in Higher Education, 30(2), 184-194. 2018.

11. N. al-Kaabneh, \& A. Hussein. " The extent to which Physical Education Colleges students implement active learning skills from the viewpoint of faculty members in Jordanian universities". Dirasat: Educational Sciences, 46 (1). 2019. (Arabic)

12. R. Wilke. "The effect of active learning on student characteristics in a human physiology course for nonmajors". Advances in physiology education, 27(4), 207-223. 2003.

13. W. Ayasreh,. "Degree of practicing active learning strategies during field training, from the perspective of graduate females from Education Faculty at Hail University". Hail University Journal 3(27). 2019. (Arabic)

14. D. Vandiver \& J, Walsh. "Assessing autonomous learning experiences in research methods courses:
Implementing the student driven research project." Journal of Active Learning, 11(1), 31-42. 2010.

15. C. Bonwell, \& J. Eison,. "Active learning: Creating excitement in the classroom" ASHE-ERIC Higher Education Report No. 1. Washington, DC: George Washington University. 1991.

16. A. Lumpkin. \& R, Dodd. "Student perceptions of active learning". College Student Journal, 49(1), 121-133. 2015.

17. C. Meyers \& T. Jones. "Promoting active learning: Strategies for the college classroom". San Francisco, CA: Jossey-Bass. 1993.

18. S. Unrah \& B. Obeidat "Adjusting to learning in the US: Saudi students speak out". Journal of Higher Education Theory and Practice, 15(4), 45-56. 2015.

19. G. Mark. "Teaching other teachers how to teach CS better" . Commun. ACM 64, 5 (May 2021), 8-9. DOI:https://doi.org/10.1145/3453647

20. Al.Baha University. "The Department of Faculty's skills development" Retreated: https://bu.edu.sa/en/web/administration-of-facultymembers-skills.

21. A. Alsmainy. "The reality of the use by faculty members at King Saud University of active learning strategies in teaching Arabic language "from the student's point of view of the College of Arts.". Saudi Journal of Educational Sciences - Issue 63 Riyadh (Majadi Al-Akhira 1440 AH / February 2019 CE). [Arabic]. 